18 Taylor SF, Liberzon I, Decker LR, Koeppe RA. A functional anatomic study of emotion in schizophrenia. Schizophr Res 2002; 58: 159-72.

19 Paradiso S, Andreasen NC, Crespo-Facoro B, O'Leary DS, Watkins GL, Boles Ponto LL, Hichwa RD. Emotions in unmedicated patients with schizophrenia during evaluation with positron emission tomography. Am J Psychiatry 2003; 160: $1775-83$.

20 Williams LM, Das P, Harris AW, Liddell BB, Brammer MJ, Olivieri G, Skerrett D, Phillips ML, David AS, Peduto A, Gordon E. Dysregulation of arousal and amygdala-prefrontal systems in paranoid schizophrenia. Am J Psychiatry 2004; 161: 480-89.

21 Taylor SF, Phan KL, Britton JC, Liberzon I. Neural responses to emotional salience in schizophrenia. Neuropsychopharmacology 2005; 30: 984-95.

22 Johnston PJ, Stojanov W, Devir H, Schall U. Functional MRI of facial emotion recognition deficits in schizophrenia and their electrophysiological correlates. Eur J Neurosci 2005; 22: 1221-32.

23 Mitchell RLC, Elliott R, Barry M, Cruttenden A, Woodruff PW. Neural response to emotional prosody in schizophrenia and in bipolar affective disorder. $\mathrm{Br} \mathrm{J}$ Psychiatry 2004; 184: 223-30.

24 Adolphs R. The neurobiology of social cognition. Curr Opin Neurobiol 2001; 11: 231-39.

25 Allison T, Puce A, McCarthy G. Social perception from visual cues: role of the STS region. Trends Cogn Sci 2000; 4: 267-78.
26 Gallagher HL, Frith CD. Functional imaging of 'theory of mind'. Trends Cogn Sci 2003; 7: 77-83.

27 Van't Wout M, Aleman A, Kessels RPC, Cahn W, de Haan EH, Kahn RS Exploring the nature of facial affect processing deficits in schizophrenia. Psychiatry Res 2007; 150: 227-35.

28 Corcoran R, Mercer G, Frith CD. Schizophrenia, symptomatology and social inference: investigating 'theory of mind' in people with schizophrenia. Schizophr Res 1995; 17: 5-13.

29 Frith $C D$, Corcoran R. Exploring 'theory of mind' in people with schizophrenia. Psychol Med 1996; 26: 521-30.

30 Pickup GJ, Frith CD. Theory of mind impairments in schizophrenia: symptomatology, severity and specificity. Psychol Med 2001; 31: 207-20.

31 Addington J, Addington D. Neurocognitive and social functioning in schizophrenia: a 2.5 year follow-up study. Schizophr Bull 2000; 44: 47-56.

32 Phan KL, Wager T, Taylor SF, Liberzon I. Functional neuroanatomy of emotion: a meta-analysis of emotion activation studies in PET and fMRI. Neuroimage 2002; 16: 331-48.

33 Talairach J, Tournoux P. Co-Planar Stereotaxic Atlas of the Human Brain. Thieme, 1988.

\title{
Erotic Dreams in Normal Persons [II Sogno Erotico nell'uomo normale]. (Riv. di Psicol., January-February, 1908.) Gualino, L.
}

The subject of sexual activity during sleep has been touched on by various psychologists and alienists and studied in detail in a few individual cases. Gualino appears to be the first to investigate it on a larger scale, and bases his paper on the experiences of 100 persons among his acquaintances, doctors, teachers, etc. (apparently all men), to whom he addressed a series of questions. They had all had experience of the phenomenon which Gualino regards as entirely normal.

Gualino finds that erotic dreams, with emissions (whether or not seminal), began somewhat earlier than the period of physical development as ascertained by Marro for youths of the same part of northern Italy. Gualino found that all his casss had had erotic dreams at the age of seventeen; Marro found 8 per cent. of youths still sexually undeveloped at that age, and while sexual development began at thirteen years erotic dreams began at twelve. Their appearance was preceded in most cases for some months by erections. In 37 per cent. of the cases there had been no actual sexual experiences (either masturbation or intercourse); in 23 per cent. there had been masturbation; in the rest some form of sexual content. The dreams are mainly visual, tactual elements coming second, and the dramatis persona is either an unknown woman (27 per cent. cases) or only known by sight (56 per cent.), and in the majority is, at all events in the beginning, an ugly or fantastic figure, becoming more attractive later in life, but never identical with the woman loved during waking life. This, as Gualino points out, accords with the general tendency for the emotions of the day to be latent in sleep. Masturbation only formed the subject of the dream in four cases. The emotional state in the pubertal stage, apart from pleasure, was anxiety (37 per cent.), desire (17 per cent.), fear (14 per cent.). In the adult stage anxiety and fear receded to 7 per cent. and 6 per cent. respectively. Thirty-three of the subjects, as a result of sexual or general disturbances, had had nocturnal emissions without dreams; these were always found exhausting. Normally (in more than 90 per cent.), erotic dreams are the most vivid of all dreams. In no case was there knowledge of any monthly or other cyclic periodicity in the occurrence of the manifestations. In 34 per cent. of cases they tended to occur very soon after sexual intercourse. In numerous cases they were peculiarly frequent (even three in one night) during courtship, when the young man was in the habit of kissing and caressing his betrothed, but ceased after marriage. It was not noted that position in bed or a full bladder exerted any marked influence in the occurrence of erotic dreams; repletion of the seminal vesicles is regarded as the main factor. 